\title{
Search for useful biomarkers in hepatocellular carcinoma, tumor factors and background liver factors (Review)
}

\author{
DAI SHIMIZU, YOSHIKUNI INOKAWA, FUMINORI SONOHARA, KENICHI INAOKA and SHUJI NOMOTO \\ Department of Surgery, Aichi Gakuin University School of Dentistry, Chikusa-ku, Nagoya 464-8651, Japan
}

Received December 21, 2016; Accepted February 9, 2017

DOI: $10.3892 /$ or.2017.5541

\begin{abstract}
Hepatocarcinogenesis is a complex and multistep process that involves the accumulation of genetic and epigenetic alterations in regulatory genes. To understand the development of hepatocellular carcinoma (HCC), current research has utilized improved array technologies. The identification of cancer-related molecules could lead to the development of novel molecular targets for treatment and biomarkers for predicting prognosis. However, prognostic prediction is insufficient when considering only tumor factors, since hepatocarcinogenesis is also greatly influenced by the status of the background liver. Clinical background liver factors, such as the presence of chronic active hepatitis or cirrhosis, are well known as risk factors for developing HCC. In contrast, genetic or epigenetic background liver factors remain unknown, albeit those are important to understand the developing process of HCC. Investigating background liver factors could contribute to the development of carcinogenic markers of HCC and to the prevention of the development of HCC. In the present study, we review the currently identified tumor factors and background liver factors from a molecular biological viewpoint and also introduce our combination array analysis.
\end{abstract}

\section{Contents}

1. Introduction

2. Tumor factors

3. Background liver factors

4. Conclusions

Correspondence to: Dr Shuji Nomoto, Department of Surgery, Aichi Gakuin University School of Dentistry, 2-11 Suemori-dori, Chikusa-ku, Nagoya 464-8651, Japan

E-mail: snomoto@dpc.agu.ac.jp

Key words: hepatocellular carcinoma, microarray, oncogene, tumor-suppressor gene, background liver

\section{Introduction}

Hepatocellular carcinoma (HCC) is one of the most common causes of cancer-related death worldwide. HCC is associated with a high recurrence rate after curative resection. There is currently no effective adjuvant chemotherapy available for HCC, and treatment options for advanced or recurrent HCC are limited. Additionally, the current tumor markers for $\mathrm{HCC}, \alpha$-fetoprotein and prothrombin induced by vitamin $\mathrm{K}$ absence or antagonist-2, are not ideal owing to their relatively low sensitivity and specificity. Thus, identification of novel molecular targets for treating recurrence and biomarkers for predicting prognosis are urgently required.

Investigation of the genetic and epigenetic alterations in the hepatocarcinogenic stage which lead to the activation of oncogenes and the inactivation or loss of tumor-suppressor genes may further our understanding of the development of HCC. Many HCC-related molecules have been recently identified as tumor factors, in part as a result of the improvement of the array technology that was first established by Grunstein and Hogness in 1975 (1). The genes that are upregulated or downregulated in HCC tissue may become the novel molecular targets for treatment or biomarkers for predicting prognosis.

HCC recurs in residual liver in $80 \%$ of patients who undergo curative resection (2). Postoperative recurrence in the residual liver arises from either a monoclonal origin caused by intrahepatic metastasis (IM) or multicentric occurrence (MO). IM develops from tumor cells that spread into the remnant liver via the portal vein before or during hepatic resection. $\mathrm{MO}$ is a unique recurrence pattern from the background liver status such as liver cirrhosis secondary to infection with hepatitis $\mathrm{B}$ virus or hepatitis $\mathrm{C}$ virus, alcoholic liver disease and non-alcoholic steatohepatitis. Several studies from developed countries have shown that $\mathrm{MO}$ recurrence is more common than IM recurrence (3-7). However, other studies have shown that IM recurrence is more common than MO recurrence $(8,9)$. The incidence of IM and MO recurrence may depend on the balance of tumor malignancy and background liver status (10). For example, advanced stage primary HCC lesions may have more accumulated epigenetic alterations and the rate of IM rate increases. Pervasion of HCC screening for high-risk patients increases the number of patients diagnosed in the early stage. HCC diagnosed at an early stage may be cured by surgical procedures, in which case MO recurrence becomes the major issue. This may be one of the reasons why the incidence of 
MO recurrence is more common than IM recurrence in developed countries. Although the incidence of HCC is highest in eastern Asia and Africa, the incidence is steadily increasing in Western countries. Thus, epigenetic understanding of MO is critical. However, most epigenetic studies concerning HCC have mostly focused only on tumor factors. Recent studies have initiated the investigation of background liver factors in $\mathrm{HCC}$, and we also pursued the detection of background liver factors using combination array analysis. In the present review, we review the recent literature regarding tumor factors as well as background liver factors in HCC patients from a genetic and epigenetic viewpoint.

\section{Tumor factors}

Numerous studies have revealed the genetic and epigenetic alterations in HCC tissue. The ongoing development and improvement in array technology have contributed to the steady increase in these findings. Furthermore, some researchers have combined existing array technologies to establish combination array analysis to effectively extract tumor factors. Moreover, it is expected that the establishment of next-generation sequencing may accelerate the identification of HCC-related factors. The investigation into tumor factors is necessary for the discovery of novel molecular targets for treatment and biomarkers for predicting prognosis. In the present study, we review the upregulated molecules in HCC as oncogene candidates and downregulated molecules as tumor-suppressor gene (TSG) candidates. Oncogenes have the potential to become therapeutic targets directly or tumor markers for liquid biopsy, thus the exploitation of oncogenes is very important. TSGs are not conducive for use as direct therapeutic targets, although novel therapeutic strategies can be developed by investigating the suppression mechanism of a TSG and the downstream pathway of the TSG. We also review the current findings on microRNAs (miRNAs), which are often reported as negative regulators in post-transcriptional processes.

Oncogenes in HCC. Oncogenes are frequently upregulated in $\mathrm{HCC}$ tissues and their expression levels correlate with poor prognosis or malignant phenotypes of HCC cells. In generally, oncogenes function to resist apoptosis, drive cell cycle progression and inhibit TSG expression or activities, enabling the acquirement of enhanced proliferation, migration and/or invasion ability by neoplastic cells. The identification of critical oncogenes in HCC could lead to the development of treatment targets for these unfavorable phenomenon. Additionally, when the protein encoded by an oncogene is overexpressed in serum, it may be a useful tumor marker. We listed the recently reported oncogenes in HCC in Table I (11-43) and below we discuss the current findings.

Catenin delta-1. Catenin delta-1 (CTNND1) encodes a member of the Armadillo protein family, which functions in cell adhesion and signal transduction. CTNND1 was reported to participate in epithelial-mesenchymal transition (EMT) $(44,45)$, and a large amount of data have implicated CTNND1 in the regulation of cancer development and progression (46). CTNND1 was reported as an oncogene that drives migration and metastasis $(47,48)$. Overexpression of CTNND1 has been observed in lung (49) and cervical cancer (50), pancreatic adenocarcinoma (51) and gastric cancer (52). Tang et al (16) showed that CTNND1 expression was significantly upregulated in HCC tissue, and the CTNND1 expression level was associated with shorter overall survival. Inhibition of CTNND1 expression promoted migratory and invasive capacities of HCC cells in vitro and metastasis in vivo. Additionally, the authors reported that CTNND1 plays an important role in regulating the EMT to mesenchymal-epithelial transition (MET) plasticity of HCC cells by interacting with E-cadherin, $\alpha$-catenin, $\mathrm{N}$-cadherin and vimentin and by enhancing $\mathrm{Wnt} / \beta$-catenin signaling. These studies demonstrate that CTNND1 functions as a novel tumor oncogene in HCC and may be a potential therapeutic target for HCC management.

Galectin-1. Galectin-1 (Gal-1) is a member of the family of $\beta$-galactoside-binding proteins implicated in modulating cellcell and cell-matrix interactions and regulated by HIF-1. Gal-1 has vital protumorigenic roles within the tumor microenvironment and plays a role in regulating apoptosis, cell proliferation and cell differentiation (53). Dysregulation of Gal-1 expression was found to be associated with resistance to chemotherapy through ERK pathway activation (54). Gal-1 overexpression also mediated migration and invasion in cancer cells via increased phosphorylation of AKT, mTOR and p70 kinases. Moreover, sorafenib response was impaired in HCC with dysregulated p-ERK and p-AKT activation. Zhang et al (22) found that Gal-1 elevated $\alpha v \beta 3$-integrin expression, leading to AKT activation, and that Gal-1 overexpression induced HCC cell EMT via PI3K/AKT cascade activation. This led Gal-1 to promote HCC cell invasion in vitro and lung metastasis in vivo. Clinically, this study also revealed a correlation between Gal-1 overexpression and poor HCC survival outcome. Moreover, Gal-1 expression was inversely correlated with HCC sensitivity to sorafenib in vitro. Thus, targeting Gal-1 in a subset of HCCs may be an optimal therapeutic strategy, and Gal-1 may be a biomarker for predicting the responsiveness to sorafenib treatment and for personalized treatment.

Meprin A subunit $\alpha$. Meprin A subunit $\alpha$ (MEP1A) encodes Meprin $\alpha$, a metalloprotease that belongs to the metzincin superfamily. MEP1A cleaves a wide variety of substrates, such as basement membrane proteins, protein kinases and cytokines. Abnormal MEP1A expression has been implicated in several diseases, such as inflammatory bowel disease, nephritis and Alzheimer's disease (55). MEP1A expression has been previously observed in only colorectal cancer (56); however, the mechanisms and function of MEP1A have not been reported. OuYang et al (34) revealed that expression levels of MEP1A were markedly elevated in HCC tumor tissues compared with matched adjacent non-neoplastic tissues and nonmalignant liver tissues. Clinical analysis indicated that the expression level of MEP1A in tumor tissues was correlated with tumor size, microvascular invasion, portal vein tumor thrombus (PVVT), differentiation grade, BCLC stage, TNM stage and patient survival. MEP1A overexpression increased cell migration and cell invasion in vivo and enhanced tumor metastasis in vitro. The authors also investigated the mechanism of oncogenic activity of MEP1A. Overexpression of MEP1A markedly enhanced the levels of ZEB1, vimentin and matrix MMP2 and MMP9, and concomitantly reduced the expression of E-cadherin. Together these 


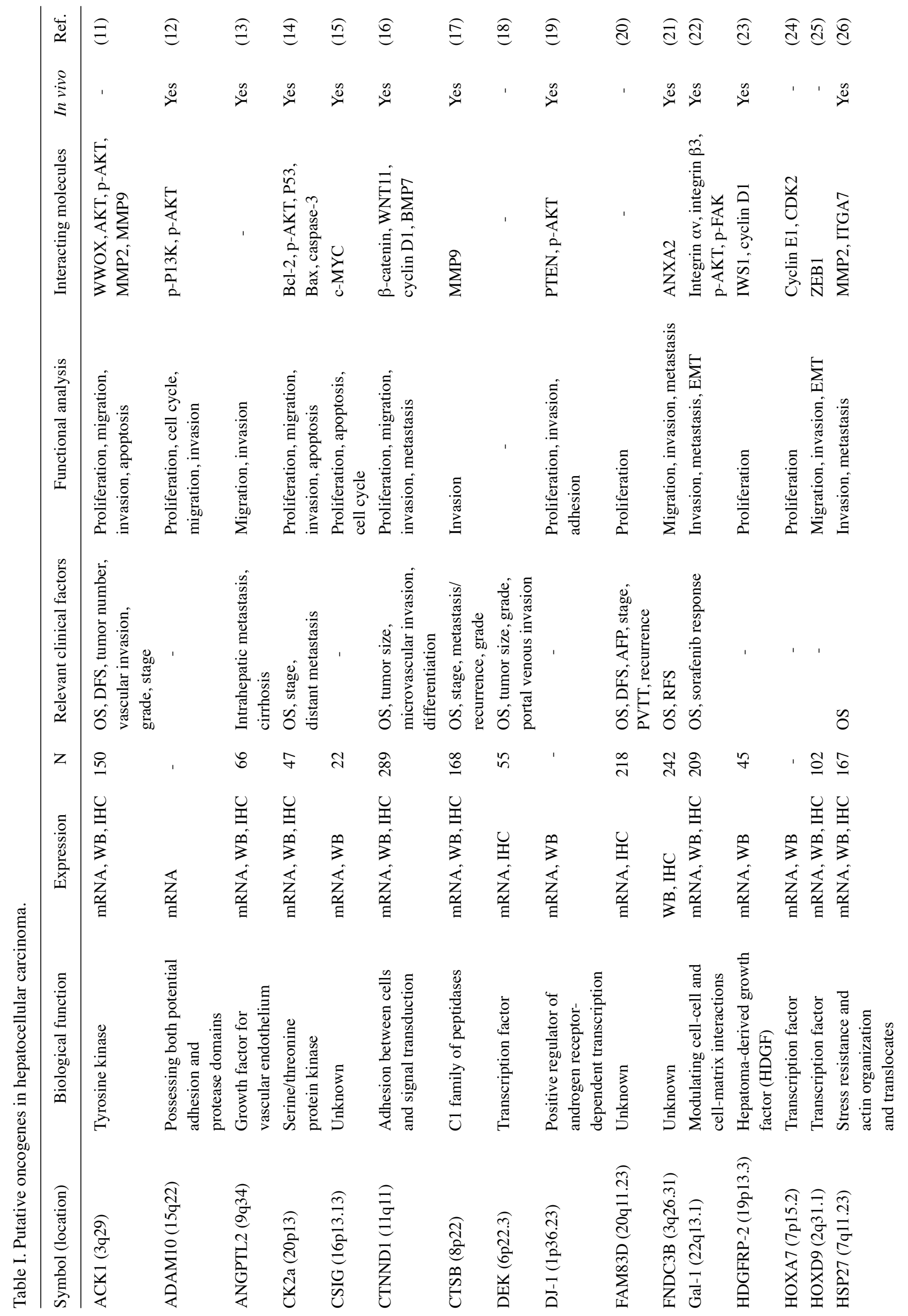




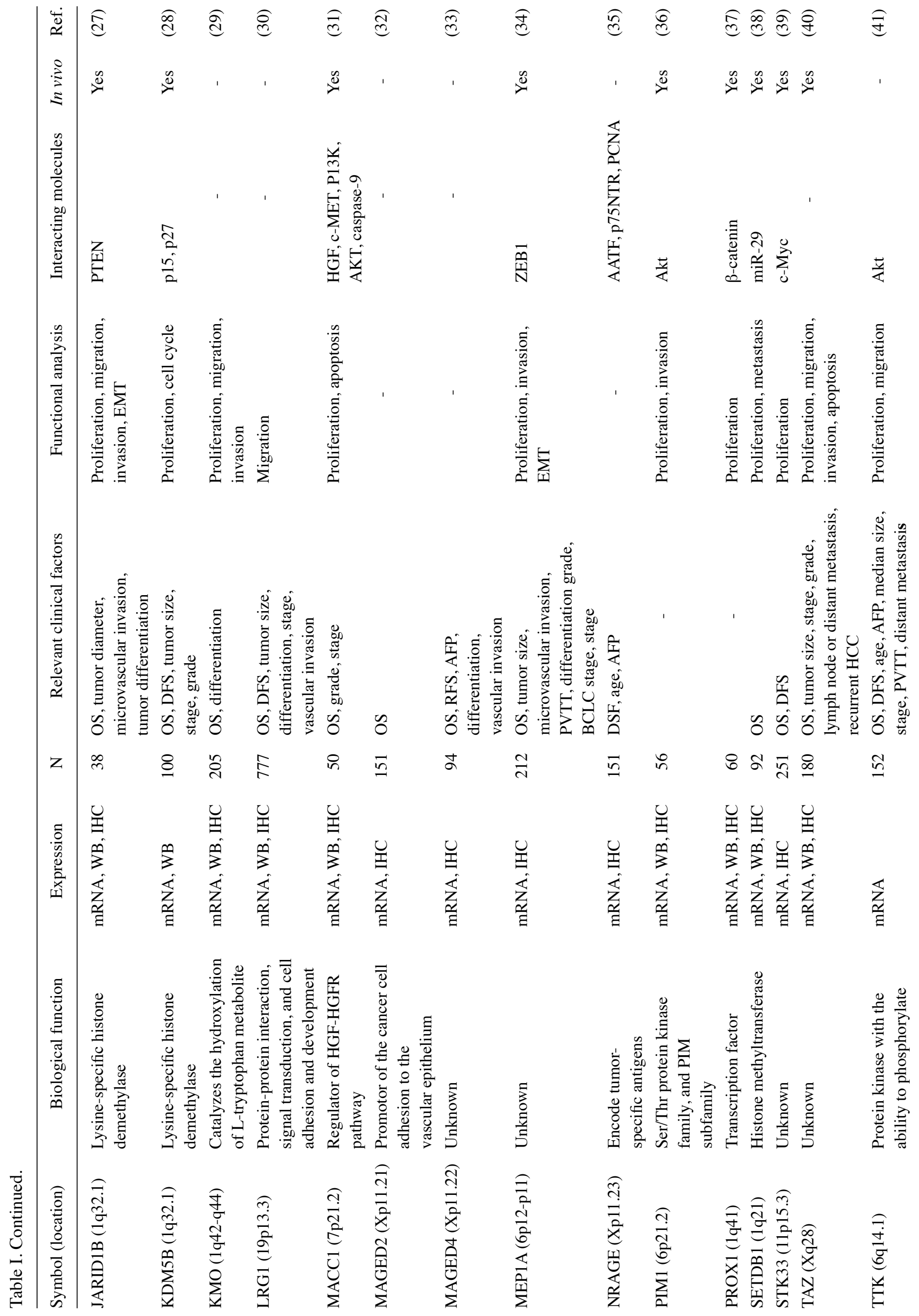


studies indicate that MEP1A is a novel prognostic predictor in $\mathrm{HCC}$ and plays an important role in the development and progression of HCC.

Serine/threonine kinase 33. Serine/threonine kinase 33 (STK33) is a serine/threonine protein kinase that belongs to the calcium/calmodulin-dependent family of kinases and is weakly expressed in the liver (57). Recently, STK33 was found to be critical for the survival of KRAS-dependent hematopoietic cancer cell lines and epithelial cancer cell lines. The kinase activity of STK33 was inferred to be required for the survival of KRAS-dependent cancer cell lines using mutations in the ATP-binding loop $(58,59)$. Yang et al (39) investigated the function and mechanism of STK33 in HCC, and STK33 expression was found to be frequently upregulated in HCC patients. Significant associations were found between increased expression of STK33 and advanced HCC staging and shorter disease-free survival of patients. Overexpression of STK33 increased HCC cell proliferation both in vitro and in vivo, whereas suppression of STK33 inhibited this effect. The authors also demonstrated that STK33 binds directly to c-Myc and increases its transcriptional activity. In particular, the C-terminus of STK33 blocked the STK33/c-Myc association, downregulated HCC cell proliferation, and reduced liver tumor cell number and tumor size. Together this suggests that STK33 plays an essential role in hepatocellular proliferation and liver tumorigenesis. The C-terminus of STK33 could be a potential therapeutic target in the treatment of patients with STK33-overexpressing HCC.

TTK protein kinase. The TTK protein kinase (TTK) gene encodes a dual specificity protein kinase that phosphorylates tyrosine, serine and threonine. TTK is essential for the mitotic checkpoint and improper chromosome attachments (60). Elevated TTK level leads to amplified centrosomes, hyperactivated SAC and chromosome instability, thus, contributing to tumorigenesis (61). The diagnostic value of TTK has been reported in thyroid carcinoma (62), breast cancer (63) and lung cancer (64). Liu et al (41) investigated the clinical significance and prognostic value of TTK in HCC and the effects on cell function and signaling pathways. The authors found that TTK mRNA expression was frequently increased in HCC tissue. High expression of TTK was significantly correlated with AFP, tumor size, advanced stage, PVTT and distant metastasis, and shortened overall survival and disease-free survival. One of the regulatory mechanisms controlling TTK in HCC was the demethylation of the TTK promoter. Inhibition of TTK expression using siRNA led to a decrease in cell proliferation and migration in vitro. Further mechanistic studies have revealed that TTK activates the Akt/mTOR pathway. Together this shows that TTK contributes to HCC tumorigenesis by promoting cell proliferation and migration, and that TTK may serve as a novel biomarker and a potential target in HCC.

TSGs in HCC. TSGs are frequently downregulated in HCC tissue and suppressed expression levels of TSGs have been correlated with poor prognosis and malignant phenotypes of HCC cells. Although TSGs are less effective for use as target molecules due to their low levels of expression in cancerous tissue, TSG expression levels in tumor tissue are useful as biomarkers. Aberrant DNA methylation, one of the mechanisms for suppression of TSG gene transcription, was 
reportedly detectable in plasma, and thus, the diagnostic significances are high (65). Additionally, TSGs serve as therapeutic targets with the use of DNA methyltransferase inhibitors or histone deacetylase inhibitors to reactivate TSGs. Moreover, downstream pathways of TSGs may provide therapeutic target candidates. We also reported several novel TSGs as potential biomarkers in HCC using a combination array analysis containing expression, single nucleotide polymorphism and methylation arrays. Table II (66-85) provides a list of putative TSGs and below we discuss several candidates.

Jumonji C domain-containing protein 5. The Jumonji C domain-containing protein (JMJD) family includes histone demethylases that can remove all methylation modifications on the lysine residues of histones (86). JMJD5 demethylates Lys-36 of histone H3. Previous studies have shown that dysregulation of JMJD5 promotes cancer cell proliferation and migration $(87,88)$. Huang et al demonstrated that JMJD5 forms a complex with the tumor suppressor p53 by interacting with the p53 DNA-binding domain and negatively regulates its activity (89). Wu et al (73) conducted an expression analysis on the JMJD family in HCC and found that the most significantly downregulated gene is the gene encoding JMJD5. The authors found that downregulation of JMJD5 was caused by altered epigenetic histone modifications on the JMJD5 promoter. JMJD5 knockdown promoted HCC cell proliferation and in vivo tumorigenicity by accelerating the G1/S transition of the cell cycle, and forced JMJD5 expression had the opposite effects. JMJD5 knockdown led to the downregulation of CDKN1A, and CDKN1A knockdown abrogated the effect of JMJD5 knockdown or overexpression on cell proliferation, suggesting that JMJD5 inhibits HCC cell proliferation mainly by activating CDKN1A expression. The authors concluded that JMJD5 is a TSG in HCC pathogenesis and that epigenetic silencing of JMJD5 promotes HCC cell proliferation by directly downregulating CDKN1A transcription.

Kallmann syndrome-1. The Kallmann syndrome-1 (KAL1) gene, also named anosmin-1, encodes an extracellular matrix related protein with a role in cellular adhesion. KAL1 promotes the migration of gonadotropin-releasing hormone expressing neurons during development (90). KAL1 also induces neurite outgrowth and cell migration through fibroblast growth factor receptor 1 pathways (91). Mutations in the KAL1 gene cause the X-linked Kallmann syndrome. Decreased KAL1 expression has been observed in colon, lung and ovarian cancers compared with corresponding adjacent normal tissues (92). Conversely, KAL1 overexpression promotes brain tumor malignancy through integrin signaling pathways (93). Tanaka et al (74) found that KAL1 was downregulated in HCC tissues in their microarray project. The authors examined the expression and methylation status of KAL1 in HCC to clarify the function of KAL1 in HCC. KAL1 mRNA expression was downregulated in HCC cell lines with promoter hypermethylation and was reactivated by demethylation by 5 -aza-dC treatment. KAL1 mRNA levels were inversely correlated with those of EZR, which is one of the key factors involved in tumor progression and metastasis in HCC (94). Downregulation of KAL1 mRNA in HCC was significantly associated with elevated AFP and PIVKA-2, larger tumor size and vascular invasion. Patients with downregulation of KAL1 were more likely to have a shorter overall survival. Multivariate analysis identified downregulation of KAL1 as an independent prognostic factor in HCC. Hence, KAL1 may serve as a biomarker of malignant phenotype of HCC.

Ras association domain family member 10. The gene encoding Ras association domain family member 10 (RASSF10) is located on chromosome 11p15.2, a region that shows frequent loss of heterozygosity $(\mathrm{LOH})$ in several cancer types. Hypermethylation of the RASSF10 promoter region, which inactivates the gene, is common across several cancers (79). Wang et al (95) examined RASSF10 expression in HCC and its role in hepatocarcinogenesis. The authors found that RASSF10 was epigenetically downregulated by promoter hypermethylation in human HCC tissue and HCC cell lines. Low RASSF10 expression was associated with poor differentiation, cirrhosis, tumor thrombus and BCLC stage and contributed to tumor recurrence and shortened patient survival. Overexpression of RASSF10 in HCC cell lines resulted in suppressed cell proliferation and apoptosis induced by Bcl-2 family proteins. In vivo, RASSF10 overexpression also reduced proliferation, migration and invasion of HCC cells by inhibiting EMT. Together, these findings indicate that RASSF10 may be a useful prognostic biomarker in HCC.

Synaptojanin-2-binding protein. Synaptojanin-2-binding protein (SYNJ2BP) regulates endocytosis of activin type II receptors (ActRIIs) through a Ral/Ral-binding protein 1-dependent pathway (96). Expression of SYNJ2BP enhances endocytosis of ActRIIs and suppresses activininduced transcription. Adam et al (97) demonstrated that SYNJ2BP stabilizes Notch ligands and inhibits sprouting angiogenesis. Notch signaling contributes to the occurrence and development of many cancers (98). Brito et al (99) used gene expression profiling to show that SYNJ2BP expression was suppressed in clear cell renal carcinoma. Liu et al (81) indicated that SYNJ2BP acted as a tumor suppressor in HCC by inhibiting tumor growth and metastasis via activation of the DLL4 pathway. To the best of our knowledge, no studies have pursued the clinical significance of SYNJ2BP in neoplasms. Liu et al further showed that SYNJ2BP mRNA and protein were downregulated in human HCC tissues and HCC cell lines. Low expression of SYNJ2BP in HCC tissues was associated with tumor size, tumor nodule number, vascular invasion, TNM stage and BCLC stage, and patients with low SYNJ2BP expression had shorter overall survival and disease-free survival. Knockdown of SYNJ2BP increased proliferation, migration and invasion activities of $\mathrm{HCC}$ cell lines in vitro, and increased tumor growth and metastasis. Additionally, knockdown of SYNJ2BP decreased DLL4 expression in HCC cell lines, and forced expression of SYNJ2BP elevated DLL4 expression. This suggests that SYNJ2BP inhibited HCC growth and metastasis through activating DLL4. Hence, SYNJ2BP can be used as a potential marker for HCC and may serve as a target for HCC treatment in the near future.

Combination array analysis. To detect cancer-related genes in HCC, we developed a new technique: a combination array analysis, consisting of a gene expression array, a methylation array and a single nucleotide polymorphism array (100). Nomoto et al previously developed the 'double-combination array' by combining expression array analysis and SNP array analysis to effectively gain whole genome information (101). 
The gene expression profile provides a snapshot of the transcriptional state of non-cancerous and tumor tissues. The SNP array is a useful tool for surveying $\mathrm{LOH}$, a prominent characteristic of many human cancers. The authors' combination of these two microarrays in one representative surgical sample enabled the identification of several, novel tumor-specific gene alterations (100-105). To further evaluate hypermethylation of promoter $\mathrm{CpG}$ islands, a methylation array can be added to complete the triple-combination array analysis, which thus, more efficiently searches for epigenetic alterations. We identified several genes as candidates for TSGs in HCC using this combination array analysis. We listed these putative TSGs detected by combination array analysis in Table III (100-112).

Dysregulated miRNAs in HCC. As a group of small non-coding RNAs, miRNAs negatively regulate post-transcriptional processes and can function as oncogenes or TSGs. miRNAs bind to complementary sequence in the target mRNA and, as a result, negatively regulates the target gene expression. miRNAs have been reported to be involved in many types of diseases particularly malignancies including HCC. miRNAs released from cancer cells into serum can be quantified by PCR technique. Some studies have demonstrated the potential value of miRNAs as prognostic or diagnostic markers. In the present review, we introduce newly identified miRNAs that potentially represent biomarkers for HCC in Table IV (113-139).

miR-192. Yang et al (140) reported the association between miR192 and HCC for the first time by genomic sequence. Previous studies have shown that miR-192 inhibited HCC growth by negatively regulating HOTTIP, and HCC patients with high HOTTIP expression had a much shorter overall survival (141). Lian et al (125) assessed the function and clinical significance of miR-192 in resected HCC specimens. miR-192 expression was decreased and negatively correlated with vascular invasion in HCC specimens. Low miR-192 expression significantly contributed to short overall survival in HCC patients. miR-192 significantly suppressed metastasis of HCC cells in vitro and in vivo. SLC39A6, which promoted HCC cell migration and invasion, was identified as a direct and functional target of miR-192. Additionally, miR-192 decreased SLC39A6 expression, subsequently downregulating SNAIL and upregulating E-cadherin expression. Thus, miR-192 and SLC39A6 may be useful predictors for HCC patient prognosis, and the miR-192/SLC39A6/SNAIL pathway may be a therapeutic target for HCC treatment.

$m i R-211$. miR-211 has been reported to be dysregulated in several carcinomas. miR-211 functions as an oncogenic miRNA in colorectal cancer (142), oral squamous cell carcinoma (143), breast (144) and lung cancer (145). In contrast, miR-211 acts as tumor suppressor in glioma (146), melanoma (147) and ovarian cancer (148). Deng et al (126) demonstrated that miR-211 is a tumor suppressor that is pathologically downregulated in HCC tissues and cell lines. miR-211 inhibited tumor cell growth, and overexpression of miR-211 suppressed HCC cell migration and invasion in vitro and in vivo. miR-211 downregulation is associated with vein invasion, TNM stage and poor overall survival of HCC patients. Moreover, SPARC was identified as a direct target of miR-211. The authors concluded that loss of miR-211 expression and thus uncontrolled SPARC overexpression may drive progression of HCC. Together, these findings may provide a novel therapeutic target for the treatment of HCC.

$m i R-379-5 p$. Chen et al (130) investigated the expression level of miR-379-5p in HCC tissues and found that downregulation of miR-379-5p was associated with advanced TNM stage. In addition, miR-379-5p expression levels were markedly lower in metastatic HCC tissues than in non-metastatic HCC tissues, indicating that miR-379-5p correlates with metastasis in HCC. Overexpression of miR-379-5p inhibited HCC cell migration, invasion, EMT and metastasis both in vitro and in vivo. Moreover, miR-379-5p was found to directly target FAK and was negatively correlated with FAK in HCC tissues. Together, this indicates that miR-379-5p may represent a novel potential therapeutic target and prognostic marker for HCC.

$m i R-519 a$. Previous studies have shown that miR-519a plays an oncogenic role in breast cancer (149) and ovarian epithelial tumors (150), and acts as a tumor suppressor in glioma (151). Shao et al (152) reported elevated expression of miR-519a in HCC tissues compared with adjacent non-cancerous tissues. The increased expression of miR-519a was significantly correlated with adverse clinical features and was associated with a poorer overall survival and recurrence-free survival of HCC patients. Upregulation of miR-519a reduced the expression of FOXF2 mRNA, promoted cell proliferation, and inhibited apoptosis in vitro. Tu et al (135) demonstrated that upregulation of miR-519a was associated with poor prognostic features and reduced overall survival and disease-free survival of HCC patients. miR-519a promoted HCC cell proliferation and cell cycle progression. Additionally, PTEN and PI3K/AKT pathway were identified as direct targets of miR-519a. These data suggest that miR-519a may be a useful diagnostic and prognostic biomarker and a novel therapeutic target for HCC.

miR-1180. Recent studies have demonstrated that low expression of miR-1180 was associated with poor overall survival in patients with renal cell carcinoma (153). miR-1180 had suppressive effects on cell proliferation and induced p21 expression, which contributed to cycle arrest, in bladder cancer cells. Tan et al (139) investigated the molecular mechanisms of miR-1180 in apoptosis resistance in HCC. miR-1180 inhibition increased cell apoptosis, while miR-1180 directly targeted OTUD7B and TNIP2, which inhibited the NF- $\mathrm{KB}$ signaling pathway. Zhou et al (154) also reported that miR-1180 promoted the proliferation of HCC cells by repressing TNIP2 expression. These studies indicate that miR-1180 may act as a tumor promoter by targeting TNIP2 and resisting apoptosis via activation of the NF- $\mathrm{BB}$ signaling pathway.

\section{Background liver factors}

Unlike other carcinomas, HCC frequently recurs in residual liver after curative surgical resection. The recurrence in residual liver shows two patterns, IM and MO. IM occurs from tumor cells that spread into the remnant liver via the portal vein from the primary lesion. MO occurs from new HCC foci that develops due to the presence of HCC-relevant risk factors in non-cancerous liver tissue $(155,156)$. Thus, hepatocarcinogenesis is greatly influenced by the state of the background liver. HCCs with MO recurrence vary in the differentiation degree and the epigenetic tumor factors in each nodule, even within a single case. However, there must 


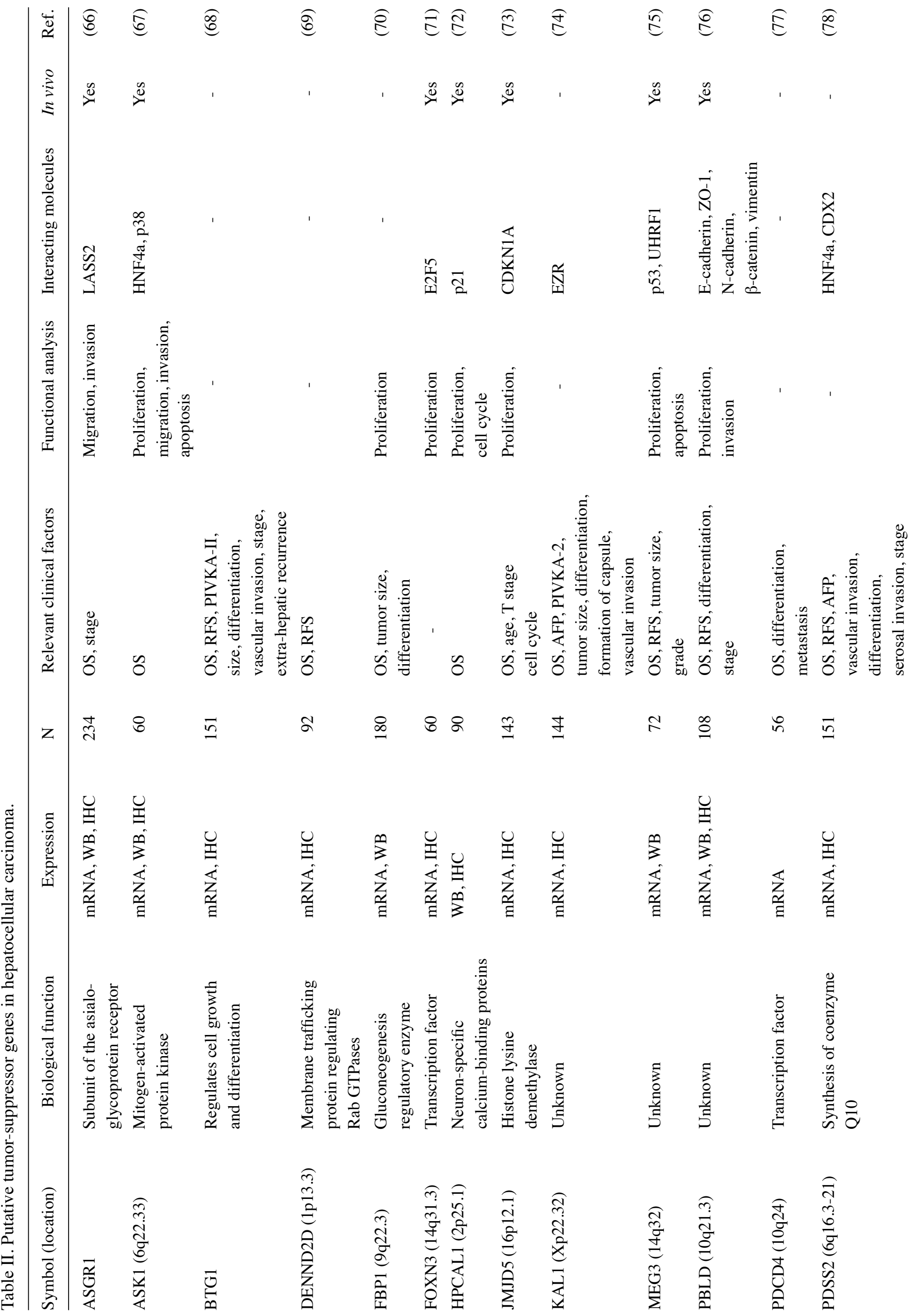




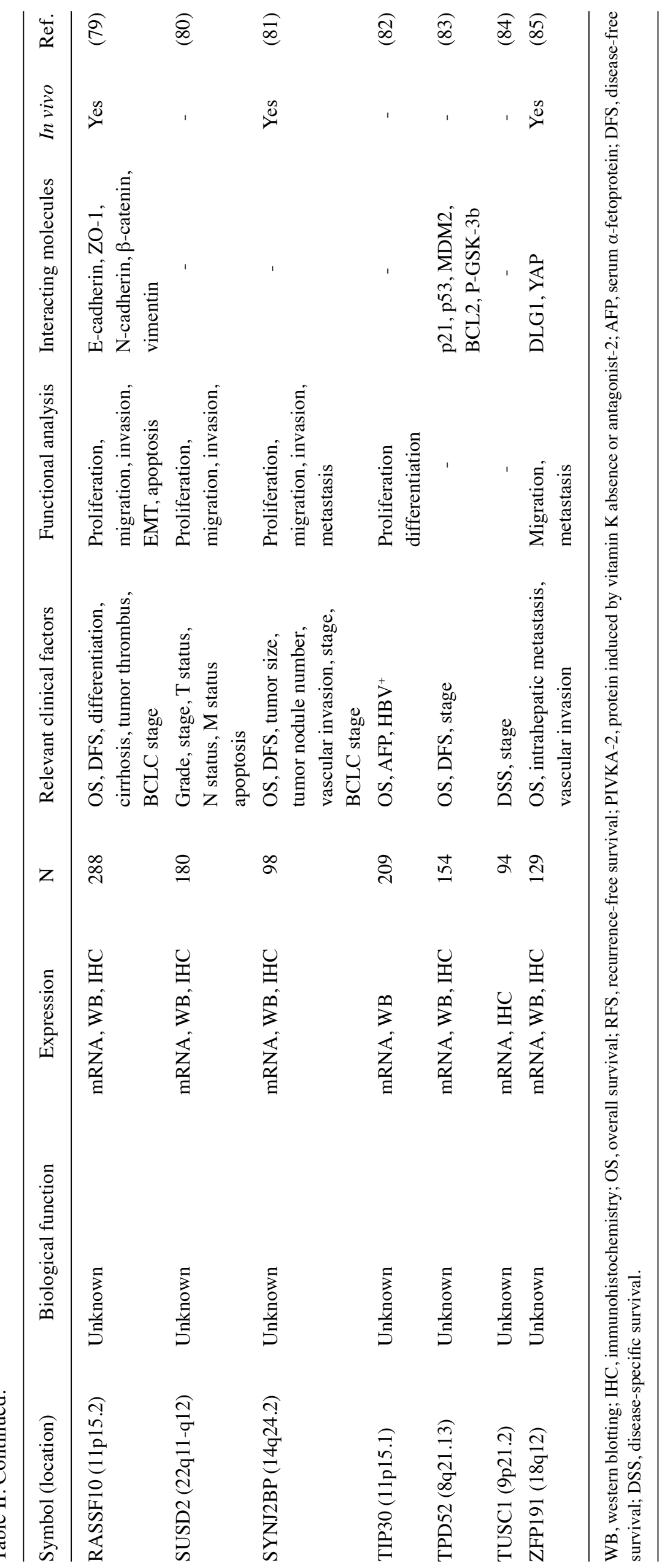


Table III. Candidate tumor-suppressor genes detected by combination array analysis.

\begin{tabular}{|c|c|c|c|c|c|c|c|}
\hline \multirow{2}{*}{$\begin{array}{l}\text { Symbol } \\
\text { (location) }\end{array}$} & \multicolumn{3}{|c|}{ Array method } & \multirow[b]{2}{*}{ No. of Pts. } & \multirow[b]{2}{*}{ Survival } & \multirow[b]{2}{*}{ Relevant clinical factors } & \multirow[b]{2}{*}{ Ref. } \\
\hline & Expression & SNP & Methylation & & & & \\
\hline MT1G (16q13) & Yes & Yes & - & 48 & - & - & (101) \\
\hline EFEMP1 (2p16) & Yes & Yes & - & 48 & OS & Liver damage, AFP & (102) \\
\hline LIFR (5p13-p12) & Yes & Yes & - & 48 & - & - & (103) \\
\hline FBLN1 (22q13.31) & Yes & Yes & - & 48 & - & $\begin{array}{l}\text { Tumor multiplicity, } \\
\text { tumor size, pStage }\end{array}$ & (104) \\
\hline BLMH (17q11.2) & Yes & Yes & Yes & 48 & - & - & (106) \\
\hline RELN (7q22) & Yes & Yes & - & 48 & DFS & - & (100) \\
\hline AKAP12 (6q24-q25) & Yes & Yes & - & 48 & OS & - & $(105)$ \\
\hline ESR1 (6q25.1) & Yes & Yes & Yes & 48 & - & - & (107) \\
\hline DNM3 (1q24.3) & Yes & Yes & Yes & 48 & DSF & Expansive growth & $(108)$ \\
\hline DCDC2 (6p22.1) & Yes & Yes & Yes & 48 & OS & - & (109) \\
\hline COL1A1 (17q21.33) & Yes & Yes & Yes & 48 & OS & $\begin{array}{l}\text { Liver damage, } \\
\text { capsule formation }\end{array}$ & (110) \\
\hline PTK7 (6p21.1-p12.2) & Yes & Yes & Yes & 48 & OS & Age, PIVKA-II & (111) \\
\hline CCNJ (10q23.33) & Yes & Yes & Yes & 85 & OS & - & (112) \\
\hline
\end{tabular}

SNP, single nucleotide polymorphism; No. of Pts., number of patients; OS, overall survival; AFP, serum $\alpha$-fetoprotein; pStage, UICC pathological stage; DFS, disease-free survival; DSF, disease-specific survival; PIVKA-II, protein induced by vitamin K absence or antagonist-2.

be some shared carcinogenic characteristics in the underlying epigenetic background of non-cancerous liver tissue in cases with MO. Identifying the mechanisms of MO may contribute to the development of carcinogenic markers for HCC and to the prevention of the development of HCC. Some researchers reported various molecular changes in the background liver of HCC patients (157-161). Okamoto et al stated that specific gene expression profiling in non-cancerous liver tissue may predict the risk of MO recurrence (157). Hoshida et al showed that gene expression profiles in non-cancerous liver tissue were associated with patient outcome (158). Utsunomiya et al reported that specific molecular signatures, including miRNAs, in non-cancerous liver tissue contributed to hepatocarcinogenesis and recurrence of HCC (159-161). However, there are few studies that refer to individual molecules in the background liver tissue of HCC. Recently, we attempted to identify these background liver factors using our combination array analysis approach. In the present review, we summarize our methods and introduce potential background liver factors.

Methods. Control samples, termed supernormal (SN) liver, were obtained from the normal tissues of 11 patients with metastatic liver cancer who underwent liver resection. For comparison, non-neoplastic liver tissue, termed corresponding normal (CN) liver, was obtained from a typical $\mathrm{HCC}$ case that resulted from chronic hepatitis $\mathrm{C}$. This patient was a 58-year old man with liver cirrhosis who had undergone liver resection but experienced recurrence 3 years after the primary lesion resection. Genomic DNA and total RNA were extracted from the $\mathrm{SN}$ and $\mathrm{CN}$ tissues. Expression profiling and methylation array were performed to compare the $\mathrm{SN}$ and
$\mathrm{CN}$ samples and identify genes with differential expression and the methylation rate.

Thimet oligopeptidase 1. Thimet oligopeptidase 1 (THOP1) was first identified as a molecule that was related to late-onset familial Alzheimer disease by Meckelein et al (162). Qi et al (163) later found that THOP1 expression was suppressed in non-small cell lung cancer and that low expression of THOP1 in cancerous tissue was correlated with poor prognosis. Nomoto et al (164) identified THOP1 as a background liver factor for hepatocarcinogenesis by combination array analysis. Expression array results showed that expression of THOP1 was decreased 4.119-fold in CN. Methylation array showed a higher value for $\mathrm{CN}(0.869)$ than $\mathrm{SN}(0.488)$. Downregulation of THOP1 was shown in HCV-positive background liver as well as in hepatitis B virus-positive and non-B non-C hepatitis virus background liver. The group with higher THOP1 expression than average showed significant correlations with prolonged survival. Strongly reduced THOP1 expression was shown to be an independent prognostic factor for overall survival. The authors concluded that expression of the THOP1 gene in the background liver of HCC is likely to be a good biomarker for the risk of HCC development.

Janus kinase 2. Janus kinase 2 (JAK2), which functions in the JAK/STAT pathway, is a tyrosine kinase involved in various processes such as cell growth, development, differentiation and histone modifications. JAD2 was found to contribute to oncogenesis through activation of STAT3 in various human solid tumor cell lines (165). The activation of the JAK/ STAT pathway in HCC was previously demonstrated by 
Table IV. Dysregulated miRNAs in hepatocellular carcinoma.

\begin{tabular}{|c|c|c|c|c|c|c|c|}
\hline miRNA & Sample & $\mathrm{N}$ & Relevant clinical factors & Functional analysis & Interacting molecules & In vivo & Ref. \\
\hline $\operatorname{miR}-7$ & Tissue & 18 & - & Proliferation & $\begin{array}{l}\text { NF90-NF45, } \\
\text { EGFR, p-AKT }\end{array}$ & - & (113) \\
\hline $\operatorname{miR}-22$ & Tissue & 162 & $\begin{array}{l}\text { OS, tumor size, } \\
\text { differentiation, stage, } \\
\text { distant metastasis }\end{array}$ & Apoptosis & Galectin-1 & - & (114) \\
\hline $\operatorname{miR}-26 b-5 p$ & Tissue & 23 & RFS & $\begin{array}{l}\text { Migration, invasion, } \\
\text { EMT }\end{array}$ & SMAD1 & Yes & $(115)$ \\
\hline miR-101 & Tissue & 20 & - & Migration, invasion & VEGF-C & - & (116) \\
\hline miR-106b & Tissue & 120 & OS, DFS, HBV $\left(^{+}\right)$ & - & $\begin{array}{l}\text { MCM7, miR-93, } \\
\text { miR-25 }\end{array}$ & - & $(117)$ \\
\hline miR-127-5p & Tissue & 111 & Grade, vascular invasion & Proliferation & NF-кB, p65, BLVRB & - & $(118)$ \\
\hline $\operatorname{miR}-133 b$ & Tissue & 37 & - & $\begin{array}{l}\text { Proliferation, invasion, } \\
\text { apoptosis }\end{array}$ & $\begin{array}{l}\text { Sirt1, E-cadherin, } \\
\text { GPC } 3, \text { Bcl-2, Bcl-xL, } \\
\text { Mcl-1, } \beta \text {-catenin }\end{array}$ & Yes & $(119)$ \\
\hline $\operatorname{miR}-135 \mathrm{a}$ & Tissue & - & - & Migration, invasion & $\begin{array}{l}\text { FOXO1, MMP2, } \\
\text { Snail, p-AKT, FOXO3a }\end{array}$ & - & $(120)$ \\
\hline miR-137 & Tissue & 110 & $\begin{array}{l}\text { OS, DSS, vascular } \\
\text { invasion, bile } \\
\text { duct invasion, AFP }\end{array}$ & - & - & & $(121)$ \\
\hline miR-144 & Tissue & 100 & Recurrence & $\begin{array}{l}\text { Invasion, metastasis, } \\
\text { cell cycle, EMT, } \\
\text { chemoresistance }\end{array}$ & SMAD4 & - & $(122)$ \\
\hline miR-155-3p & Tissue & 45 & OS & Proliferation & FBXW7 & Yes & (123) \\
\hline miR-186 & Cell line & - & - & $\begin{array}{l}\text { Proliferation, migration, } \\
\text { invasion }\end{array}$ & YAP1 & - & $(124)$ \\
\hline miR-192 & Tissue & 101 & OS, vascular invasion & Metastasis & $\begin{array}{l}\text { SNAIL, SLC39A6, } \\
\text { E-cadherin }\end{array}$ & Yes & $(125)$ \\
\hline miR-211 & Tissue & 227 & $\begin{array}{l}\text { OS, vein invasion, } \\
\text { stage }\end{array}$ & $\begin{array}{l}\text { Proliferation, migration, } \\
\text { invasion }\end{array}$ & SPARC & Yes & (126) \\
\hline $\operatorname{miR}-214$ & Tissue & 25 & - & Proliferation & $\mathrm{UCP} 2$ & - & $(127)$ \\
\hline $\operatorname{miR}-224$ & $\begin{array}{l}\text { Tissue, } \\
\text { plasma }\end{array}$ & 211 & $\begin{array}{l}\text { Tumor size, stage, } \\
\text { recurrence }\end{array}$ & - & - & - & $(128)$ \\
\hline miR-367 & Tissue & 35 & - & $\begin{array}{l}\text { Proliferation, migration, } \\
\text { invasion }\end{array}$ & PTEN & - & $(129)$ \\
\hline $\operatorname{miR}-379-5 p$ & Tissue & 85 & Stage, metastasis & $\begin{array}{l}\text { Migration, invasion, } \\
\text { EMT, metastasis }\end{array}$ & FAK & Yes & $(130)$ \\
\hline $\operatorname{miR}-449 a$ & Tissue & 40 & - & $\begin{array}{l}\text { Proliferation, migration, } \\
\text { invasion }\end{array}$ & ADAM10 & - & $(131)$ \\
\hline $\operatorname{miR}-497$ & Tissue & 86 & $\begin{array}{l}\text { OS, DFS, AFP, } \\
\text { tumor size, grade, } \\
\text { T stage }\end{array}$ & Proliferation, apoptosis & YAP1 & - & (132) \\
\hline miR-502-3P & Tissue & 50 & - & $\begin{array}{l}\text { Proliferation, invasion, } \\
\text { metastasis, cell adhesion }\end{array}$ & SET & - & (133) \\
\hline miR-503 & Tissue & 87 & $\begin{array}{l}\text { Grade, nodal metastasis, } \\
\text { vascular invasion, stage }\end{array}$ & Proliferation, apoptosis & IGF-1R & - & (134) \\
\hline $\operatorname{miR}-519 a$ & Tissue & 116 & $\begin{array}{l}\text { OS, DFS, tumor size, } \\
\text { grade, stage, } \\
\text { venous infiltration }\end{array}$ & Proliferation, cell cycle & PTEN & - & $(135)$ \\
\hline miR-613 & Tissue & 38 & - & Proliferation, invasion & DCLK1 & Yes & (136) \\
\hline miR-655-3p & Tissue & 84 & $\begin{array}{l}\text { Tumor size, PVTT, } \\
\text { differentiation, stage, } \\
\text { metastasis }\end{array}$ & $\begin{array}{l}\text { Proliferation, } \\
\text { migration, invasion }\end{array}$ & ADAM10 & - & $(137)$ \\
\hline $\operatorname{miR}-761$ & Tissue & 50 & - & Proliferation, metastasis & MFN2 & Yes & $(138)$ \\
\hline miR-1180 & Tissue & 7 & - & Proliferation, apoptosis & OTUD7B, TNIP2, BAD & Yes & (139) \\
\hline
\end{tabular}

OS, overall survival; RFS, recurrence-free survival; EMT, endothelial-mesenchymal transition; DFS, disease-free survival; DSS, disease-specific survival; AFP, serum $\alpha$-fetoprotein. 
measuring the phosphorylation of JAK/STAT proteins (166). Sonohara et al (167) reported that higher JAK2 expression in $\mathrm{CN}$ significantly correlated with shorter overall survival while JAK2 expression in HCC did not relate to prognosis statistically. The authors suggested that higher JAK2 expression in the background liver tissue of HCC could reflect carcinogenesis potential and may be a good prognostic biomarker for resected HCC.

\section{Conclusions}

The improvement in array technologies and the development of next-generation sequencing have contributed to the identification of several tumor factors in HCC that may serve as novel molecular targets for treating recurrence and biomarkers for predicting the prognosis. Further research in this direction should lead to the establishment of background liver factors, which may contribute to the development of carcinogenic markers of HCC and the prevention of the development of HCC.

\section{References}

1. Grunstein M and Hogness DS: Colony hybridization: A method for the isolation of cloned DNAs that contain a specific gene. Proc Natl Acad Sci USA 72: 3961-3965, 1975.

2. Taura K, Ikai I, Hatano E, Fujii H, Uyama N and Shimahara Y: Implication of frequent local ablation therapy for intrahepatic recurrence in prolonged survival of patients with hepatocellular carcinoma undergoing hepatic resection: An analysis of 610 patients over 16 years old. Ann Surg 244: 265-273, 2006.

3. Yamamoto T, Kajino K, Kudo M, Sasaki Y, Arakawa Y and Hino O: Determination of the clonal origin of multiple human hepatocellular carcinomas by cloning and polymerase chain reaction of the integrated hepatitis B virus DNA. Hepatology 29: 1446-1452, 1999.

4. Chen YJ, Yeh SH, Chen JT, Wu CC, Hsu MT, Tsai SF, Chen PJ and Lin $\mathrm{CH}$ : Chromosomal changes and clonality relationship between primary and recurrent hepatocellular carcinoma. Gastroenterology 119: 431-440, 2000.

5. Ochiai T, Urata Y, Yamano T, Yamagishi H and Ashihara T: Clonal expansion in evolution of chronic hepatitis to hepatocellular carcinoma as seen at an X-chromosome locus. Hepatology 31: 615-621, 2000.

6. Nomoto S, Yamashita K, Koshikawa K, Nakao A and Sidransky D: Mitochondrial D-loop mutations as clonal markers in multicentric hepatocellular carcinoma and plasma. Clin Cancer Res 8: 481-487, 2002.

7. Nomoto S, Kinoshita T, Kato K, Otani S, Kasuya H, Takeda S, Kanazumi N, Sugimoto H and Nakao A: Hypermethylation of multiple genes as clonal markers in multicentric hepatocellular carcinoma. Br J Cancer 97: 1260-1265, 2007.

8. Wang B, Xia CY, Lau WY, Lu XY, Dong H, Yu WL, Jin GZ, Cong $\mathrm{WM}$ and $\mathrm{Wu} \mathrm{MC}$ : Determination of clonal origin of recurrent hepatocellular carcinoma for personalized therapy and outcomes evaluation: A new strategy for hepatic surgery. J Am Coll Surg 217: 1054-1062, 2013.

9. Ng IO, Guan XY, Poon RT, Fan ST and Lee JM: Determination of the molecular relationship between multiple tumour nodules in hepatocellular carcinoma differentiates multicentric origin from intrahepatic metastasis. J Pathol 199: 345-353, 2003.

10. Nomoto S, Hishida M, Inokawa Y, Sugimoto H and Kodera Y: Management of hepatocellular carcinoma should consider both tumor factors and background liver factors. Hepatobiliary Surg Nutr 3: 82-85, 2014.

11. Xie B, Zen Q, Wang X, He X, Xie Y, Zhang Z and Li H: ACK1 promotes hepatocellular carcinoma progression via downregulating WWOX and activating AKT signaling. Int J Oncol 46: 2057-2066, 2015.

12. Liu S, Zhang W, Liu K, Ji B and Wang G: Silencing ADAM10 inhibits the in vitro and in vivo growth of hepatocellular carcinoma cancer cells. Mol Med Rep 11: 597-602, 2015.
13. Gao L, Ge C, Fang T, Zhao F, Chen T, Yao M, Li J and Li H: ANGPTL2 promotes tumor metastasis in hepatocellular carcinoma. J Gastroenterol Hepatol 30: 396-404, 2015.

14. Zhang HX, Jiang SS, Zhang XF, Zhou ZQ, Pan QZ, Chen CL, Zhao JJ, Tang Y, Xia JC and Weng DS: Protein kinase CK2 $\alpha$ catalytic subunit is overexpressed and serves as an unfavorable prognostic marker in primary hepatocellular carcinoma. Oncotarget 6: 34800-34817,2015.

15. Cheng Q, Yuan F, Lu F, Zhang B, Chen T, Chen X, Cheng Y, Li N, Ma L and Tong T: CSIG promotes hepatocellular carcinoma proliferation by activating c-MYC expression. Oncotarget 6: 4733-4744, 2015.

16. Tang B, Tang F, Wang Z, Qi G, Liang X, Li B, Yuan S, Liu J, Yu S and He S: Overexpression of CTNND1 in hepatocellular carcinoma promotes carcinous characters through activation of Wnt// -catenin signaling. J Exp Clin Cancer Res 35: 82, 2016.

17. Ruan J, Zheng H, Rong X, Rong X, Zhang J, Fang W, Zhao P and Luo R: Over-expression of cathepsin B in hepatocellular carcinomas predicts poor prognosis of $\mathrm{HCC}$ patients. Mol Cancer 15: 17, 2016.

18. Yi HC, Liu YL, You P, Pan JS, Zhou JY, Liu ZJ and Zhang ZY: Overexpression of $D E K$ gene is correlated with poor prognosis in hepatocellular carcinoma. Mol Med Rep 11: 1318-1323, 2015.

19. Liu S, Long G, Wei H, Shi L, Yang Z, Liu D, Hu G and Qiu H: DJ-1 knockdown inhibits growth and xenograft-induced tumor generation of human hepatocellular carcinoma cells. Oncol Rep 33: 201-206, 2015.

20. Liao W, Liu W, Liu X, Yuan Q, Ou Y, Qi Y, Huang W, Wang Y and Huang J: Upregulation of FAM $83 D$ affects the proliferation and invasion of hepatocellular carcinoma. Oncotarget 6: 24132-24147, 2015.

21. Lin CH, Lin YW, Chen YC, Liao CC, Jou YS, Hsu MT and Chen CF: FNDC $3 B$ promotes cell migration and tumor metastasis in hepatocellular carcinoma. Oncotarget 7: 49498-49508, 2016.

22. Zhang PF, Li KS, Shen YH, Gao PT, Dong ZR, Cai JB, Zhang C, Huang XY, Tian MX, Hu ZQ, et al: Galectin-1 induces hepatocellular carcinoma EMT and sorafenib resistance by activating FAK/PI3K/AKT signaling. Cell Death Dis 7: e2201, 2016.

23. Gao K, Xu C, Jin X, Wumaier R, Ma J, Peng J, Wang Y, Tang Y, Yu L and Zhang P: HDGF-related protein-2 (HRP-2) acts as an oncogene to promote cell growth in hepatocellular carcinoma. Biochem Biophys Res Commun 458: 849-855, 2015.

24. Li Y, Yang XH, Fang SJ, Qin CF, Sun RL, Liu ZY, Jiang BY, Wu X and Li G: HOXA7 stimulates human hepatocellular carcinoma proliferation through cyclin E1/CDK2. Oncol Rep 33: 990-996, 2015.

25. Lv X, Li L, Lv L, Qu X, Jin S, Li K, Deng X, Cheng L, He H and Dong L: HOXD9 promotes epithelial-mesenchymal transition and cancer metastasis by ZEB1 regulation in hepatocellular carcinoma. J Exp Clin Cancer Res 34: 133, 2015.

26. Zhang Y, Tao X, Jin G, Jin H, Wang N, Hu F, Luo Q, Shu H, Zhao F, Yao M, et al: A targetable molecular chaperone Hsp27 confers aggressiveness in hepatocellular carcinoma. Theranostics 6: 558-570, 2016.

27. Tang B, Qi G, Tang F, Yuan S, Wang Z, Liang X, Li B, Yu S, Liu J, Huang Q, et al: JARID1B promotes metastasis and epithelial-mesenchymal transition via PTEN/AKT signaling in hepatocellular carcinoma cells. Oncotarget 6: 12723-12739, 2015.

28. Wang D, Han S, Peng R, Jiao C, Wang X, Yang X, Yang R and Li X: Depletion of histone demethylase KDM5B inhibits cell proliferation of hepatocellular carcinoma by regulation of cell cycle checkpoint proteins p15 and p27. J Exp Clin Cancer Res 35: 37, 2016.

29. Jin H, Zhang Y, You H, Tao X, Wang C, Jin G, Wang N, Ruan H, $\mathrm{Gu} \mathrm{D}$, Huo $\mathrm{X}$, et al: Prognostic significance of kynurenine 3-monooxygenase and effects on proliferation, migration, and invasion of human hepatocellular carcinoma. Sci Rep 5: 10466 , 2015.

30. Wang CH, Li M, Liu LL, Zhou RY, Fu J, Zhang CZ and Yun JP: LRG1 expression indicates unfavorable clinical outcome in hepatocellular carcinoma. Oncotarget 6: 42118-42129, 2015.

31. Yao Y, Dou C, Lu Z, Zheng X and Liu Q: MACC1 suppresses cell apoptosis in hepatocellular carcinoma by targeting the HGF/c-MET/AKT pathway. Cell Physiol Biochem 35: 983-996, 2015.

32. Hashimoto R, Kanda M, Takami H, Shimizu D, Oya H, Hibino S, Okamura Y, Yamada S, Fujii T, Nakayama G, et al: Aberrant expression of melanoma-associated antigen-D2 serves as a prognostic indicator of hepatocellular carcinoma outcome following curative hepatectomy. Oncol Lett 9: 1201-1206, 2015. 
33. Takami H, Kanda M, Oya H, Hibino S, Sugimoto H, Suenaga M, Yamada S, Nishikawa Y, Asai M, Fujii T, et al: Evaluation of MAGE-D4 expression in hepatocellular carcinoma in Japanese patients. J Surg Oncol 108: 557-562, 2013.

34. OuYang HY, Xu J, Luo J, Zou RH, Chen K, Le Y, Zhang YF, Wei W, Guo RP and Shi M: MEP1A contributes to tumor progression and predicts poor clinical outcome in human hepatocellular carcinoma. Hepatology 63: 1227-1239, 2016.

35. Shimizu D, Kanda M, Sugimoto H, Sueoka S, Takami H, Ezaka K, Tanaka Y, Hashimoto R, Okamura Y, Iwata N, et al: NRAGE promotes the malignant phenotype of hepatocellular carcinoma. Oncol Lett 11: 1847-1854, 2016.

36. Leung CO, Wong CC, Fan DN, Kai AK, Tung EK, Xu IM, $\mathrm{Ng}$ IO and Lo RC: PIM1 regulates glycolysis and promotes tumor progression in hepatocellular carcinoma. Oncotarget 6 : 10880-10892, 2015.

37. Liu Y, Ye X, Zhang JB, Ouyang H, Shen Z, Wu Y, Wang W, Wu J, Tao S, Yang X, et al: PROX1 promotes hepatocellular carcinoma proliferation and sorafenib resistance by enhancing $\beta$-catenin expression and nuclear translocation. Oncogene 34: 5524-5535, 2015.

38. Wong CM, Wei L, Law CT, Ho DW, Tsang FH, Au SL, Sze KM, Lee JM, Wong CC and Ng IO: Up-regulation of histone methyltransferase SETDB1 by multiple mechanisms in hepatocellular carcinoma promotes cancer metastasis. Hepatology 63: 474-487, 2016.

39. Yang T, Song B, Zhang J, Yang GS, Zhang H, Yu WF, Wu MC, Lu JH and Shen F: STK33 promotes hepatocellular carcinoma through binding to c-Myc. Gut 65: 124-133, 2016.

40. Guo Y, Pan Q, Zhang J, Xu X, Liu X, Wang Q, Yi R, Xie X, Yao L, Liu W, et al: Functional and clinical evidence that TAZ is a candidate oncogene in hepatocellular carcinoma. J Cell Biochem 116: 2465-2475, 2015.

41. Liu X, Liao W, Yuan Q, Ou Y and Huang J: TTK activates Akt and promotes proliferation and migration of hepatocellular carcinoma cells. Oncotarget 6: 34309-34320, 2015

42. Zhang XF, Pan QZ, Pan K, Weng DS, Wang QJ, Zhao JJ, He J, Liu Q, Wang DD, Jiang SS, et al: Expression and prognostic role of ubiquitination factor E4B in primary hepatocellular carcinoma. Mol Carcinog 55: 64-76, 2016.

43. Zhang XF, Chao J, Pan QZ, Pan K, Weng DS, Wang QJ, Zhao JJ, He J, Liu Q, Jiang SS, et al: Overexpression of WWP1 promotes tumorigenesis and predicts unfavorable prognosis in patients with hepatocellular carcinoma. Oncotarget 6: 40920-40933, 2015.

44. Chai JY, Modak C, Mouazzen W, Narvaez R and Pham J: Epithelial or mesenchymal: Where to draw the line? Biosci Trends 4: 130-142, 2010.

45. Lu Q: $\delta$-Catenin dysregulation in cancer: Interactions with E-cadherin and beyond. J Pathol 222: 119-123, 2010.

46. Schackmann RC, Tenhagen M, van de Ven RA and Derksen PW: p120-catenin in cancer - mechanisms, models and opportunities for intervention. J Cell Sci 126: 3515-3525, 2013.

47. Zhang L, Liu YL, Chen GX, Cui B, Wang JS, Shi YL, Li LP and Guo XB: Heme oxygenase-1 promotes Caco-2 cell proliferation and migration by targeting CTNND1. Chin Med J 126 3057-3063, 2013

48. Li T, Lai Q, Wang S, Cai J, Xiao Z, Deng D, He L, Jiao H, Ye Y, Liang L, et al: MicroRNA-224 sustains Wnt/ $\beta$-catenin signaling and promotes aggressive phenotype of colorectal cancer. J Exp Clin Cancer Res 35: 21, 2016.

49. Castillo SD, Angulo B, Suarez-Gauthier A, Melchor L Medina PP, Sanchez-Verde L, Torres-Lanzas J, Pita G, Benitez J and Sanchez-Cespedes M: Gene amplification of the transcription factor DP1 and CTNND1 in human lung cancer. J Pathol 222: 89-98, 2010.

50. Noordhuis MG, Fehrmann RS, Wisman GB, Nijhuis ER, van Zanden JJ, Moerland PD, Ver Loren van Themaat E, Volders HH, Kok M, ten Hoor KA, et al: Involvement of the TGF-beta and beta-catenin pathways in pelvic lymph node metastasis in early-stage cervical cancer. Clin Cancer Res 17: $1317-1330,2011$

51. Mann KM, Ward JM, Yew CC, Kovochich A, Dawson DW, Black MA, Brett BT, Sheetz TE, Dupuy AJ, Chang DK, et al; Australian Pancreatic Cancer Genome Initiative: Sleeping Beauty mutagenesis reveals cooperating mutations and pathways in pancreatic adenocarcinoma. Proc Natl Acad Sci USA 109: 5934-5941, 2012

52. Xing AY, Wang YW, Su ZX, Shi DB, Wang B and Gao P. Catenin- $\delta 1$, negatively regulated by miR-145, promotes tumour aggressiveness in gastric cancer. J Pathol 236: 53-64, 2015.
53. Ito K, Stannard K, Gabutero E, Clark AM, Neo SY, Onturk S, Blanchard $\mathrm{H}$ and Ralph SJ: Galectin-1 as a potent target for cancer therapy: Role in the tumor microenvironment. Cancer Metastasis Rev 31: 763-778, 2012.

54. Zhang P, Zhang P, Shi B, Zhou M, Jiang H, Zhang H, Pan X, Gao H, Sun H and Li Z: Galectin-1 overexpression promotes progression and chemoresistance to cisplatin in epithelial ovarian cancer. Cell Death Dis 5: e991, 2014.

55. Broder C and Becker-Pauly C: The metalloproteases meprin $\alpha$ and meprin $\beta$ : Unique enzymes in inflammation, neurodegeneration, cancer and fibrosis. Biochem J 450: 253-264, 2013.

56. Lottaz D, Maurer CA, Hahn D, Büchler MW and Sterchi EE: Nonpolarized secretion of human meprin alpha in colorectal cancer generates an increased proteolytic potential in the stroma. Cancer Res 59: 1127-1133, 1999.

57. Mujica AO, Brauksiepe B, Saaler-Reinhardt S, Reuss S and Schmidt ER: Differential expression pattern of the novel serine/threonine kinase, STK33, in mice and men. FEBS J 272: 4884-4898, 2005.

58. Azoitei N, Hoffmann CM, Ellegast JM, Ball CR, Obermayer K, Gößele U, Koch B, Faber K, Genze F, Schrader M, et al: Targeting of KRAS mutant tumors by HSP90 inhibitors involves degradation of STK33. J Exp Med 209: 697-711, 2012.

59. Scholl C, Fröhling S, Dunn IF, Schinzel AC, Barbie DA, Kim SY, Silver SJ, Tamayo P, Wadlow RC, Ramaswamy S, et al: Synthetic lethal interaction between oncogenic KRAS dependency and STK33 suppression in human cancer cells. Cell 137: 821-834, 2009.

60. Jelluma N, Brenkman AB, van den Broek NJ, Cruijsen CW, van Osch MH, Lens SM, Medema RH and Kops GJ: Mps1 phosphorylates Borealin to control Aurora B activity and chromosome alignment. Cell 132: 233-246, 2008.

61. Zhang L, Shi R, He C, Cheng C, Song B, Cui H, Zhang Y, Zhao Z, Bi Y, Yang X, et al: Oncogenic B-Raf ${ }^{\mathrm{V} 600 \mathrm{E}}$ abrogates the AKT/B-Raf/Mps1 interaction in melanoma cells. Cancer Lett 337: 125-132, 2013.

62. Salvatore G, Nappi TC, Salerno P, Jiang Y, Garbi C, Ugolini C, Miccoli P, Basolo F, Castellone MD, Cirafici AM, et al: A cell proliferation and chromosomal instability signature in anaplastic thyroid carcinoma. Cancer Res 67: 10148-10158, 2007.

63. Maire V, Baldeyron C, Richardson M, Tesson B, VincentSalomon A, Gravier E, Marty-Prouvost B, De Koning L, Rigaill G, Dumont A, et al: TTK/hMPS1 is an attractive therapeutic target for triple-negative breast cancer. PLoS One 8: e63712, 2013

64. Landi MT, Dracheva T, Rotunno M, Figueroa JD, Liu H, Dasgupta A, Mann FE, Fukuoka J, Hames M, Bergen AW, et al: Gene expression signature of cigarette smoking and its role in lung adenocarcinoma development and survival. PLoS One 3: e1651, 2008.

65. Kawakami K, Brabender J, Lord RV, Groshen S, Greenwald BD, Krasna MJ, Yin J, Fleisher AS, Abraham JM, Beer DG, et al: Hypermethylated APC DNA in plasma and prognosis of patients with esophageal adenocarcinoma. J Natl Cancer Inst 92: 1805-1811, 2000.

66. Gu D, Jin H, Jin G, Wang C, Wang N, Hu F, Luo Q, Chu W, Yao $\mathrm{M}$ and Qin W: The asialoglycoprotein receptor suppresses the metastasis of hepatocellular carcinoma via LASS2mediated inhibition of V-ATPase activity. Cancer Lett 379: 107-116, 2016.

67. Jiang CF, Wen LZ, Yin C, Xu WP, Shi B, Zhang X and Xie WF: Apoptosis signal-regulating kinase 1 mediates the inhibitory effect of hepatocyte nuclear factor- $4 \alpha$ on hepatocellular carcinoma. Oncotarget 7: 27408-27421, 2016.

68. Kanda M, Sugimoto H, Nomoto S, Oya H, Hibino S, Shimizu D, Takami H, Hashimoto R, Okamura Y, Yamada S, et al: B-cell translocation gene 1 serves as a novel prognostic indicator of hepatocellular carcinoma. Int J Oncol 46: 641-648, 2015.

69. Kanda M, Nomoto S, Oya H, Takami H, Hibino S, Hishida M, Suenaga M, Yamada S, Inokawa Y, Nishikawa Y, et al: Downregulation of $D E N N D 2 D$ by promoter hypermethylation is associated with early recurrence of hepatocellular carcinoma. Int J Oncol 44: 44-52, 2014.

70. Hirata H, Sugimachi K, Komatsu H, Ueda M, Masuda T, Uchi R, Sakimura S, Nambara S, Saito T, Shinden Y, et al: Decreased expression of fructose-1,6-bisphosphatase associates with glucose metabolism and tumor progression in hepatocellular carcinoma. Cancer Res 76: 3265-3276, 2016. 
71. Sun J, Li H, Huo Q, Cui M, Ge C, Zhao F, Tian H, Chen T, Yao M and $\mathrm{Li}$ J: The transcription factor FOXN3 inhibits cell proliferation by downregulating E2F5 expression in hepatocellular carcinoma cells. Oncotarget 7: 43534-43545, 2016.

72. Zhang Y, Liu Y, Duan J, Yan H, Zhang J, Zhang H, Fan Q, Luo F, Yan G, Qiao K, et al: Hippocalcin-like 1 suppresses hepatocellular carcinoma progression by promoting $\mathrm{p} 21^{\text {Waf/Cipl }}$ stabilization by activating the ERK1/2-MAPK pathway. Hepatology 63: 880-897, 2016.

73. Wu BH, Chen H, Cai CM, Fang JZ, Wu CC, Huang LY, Wang L and Han ZG: Epigenetic silencing of JMJD5 promotes the proliferation of hepatocellular carcinoma cells by down-regulating the transcription of CDKN1A 686. Oncotarget 7: 6847-6863, 2016.

74. Tanaka Y, Kanda M, Sugimoto H, Shimizu D, Sueoka S, Takami H, Ezaka K, Hashimoto R, Okamura Y, Iwata N, et al: Translational implication of Kallmann syndrome-1 gene expression in hepatocellular carcinoma. Int J Oncol 46: 2546-2554, 2015.

75. Zhuo H, Tang J, Lin Z, Jiang R, Zhang X, Ji J, Wang P and Sun B: The aberrant expression of MEG3 regulated by UHRF1 predicts the prognosis of hepatocellular carcinoma. Mol Carcinog 55 209-219, 2016.

76. Li A, Yan Q, Zhao X, Zhong J, Yang H, Feng Z, Du Y, Wang Y, Wang Z, Wang H, et al: Decreased expression of PBLD correlates with poor prognosis and functions as a tumor suppressor in human hepatocellular carcinoma. Oncotarget 7: 524-537, 2016

77. Ding $X$, Cheng $X$, Gong $M$, Chen X, Yin F and Lai K Hypermethylation and expression silencing of PDCD4 gene in hepatocellular carcinoma: A consort study. Medicine 95: e2729, 2016.

78. Kanda M, Sugimoto H, Nomoto S, Oya H, Shimizu D, Takami H, Hashimoto R, Sonohara F, Okamura Y, Yamada S, et al: Clinical utility of $P D S S 2$ expression to stratify patients at risk for recurrence of hepatocellular carcinoma. Int J Oncol 45: 20052012, 2014

79. Richter AM, Walesch SK, Würl P, Taubert H and Dammann RH: The tumor suppressor RASSF10 is upregulated upon contact inhibition and frequently epigenetically silenced in cancer. Oncogenesis 1: e18, 2012.

80. Liu XR, Cai CX, Luo LM, Zheng WL, Shi R, Zeng J, Xu YQ, Wei $M$ and Ma WL: Decreased expression of Sushi Domain Containing 2 correlates to progressive features in patients with hepatocellular carcinoma. Cancer Cell Int 16: 15, 2016.

81. Liu X, Zhou J, Zhou N, Zhu J, Feng Y and Miao X: SYNJ2BP inhibits tumor growth and metastasis by activating DLL4 pathway in hepatocellular carcinoma. J Exp Clin Cancer Res 35: 115,2016

82. Zhang X, Lv L, Ouyang X, Zhang S, Fang J, Cai L and Li D: Association of TIP30 expression and prognosis of hepatocellular carcinoma in patients with HBV infection. Cancer Med 5: 2180-2189, 2016

83. Wang Y, Chen CL, Pan QZ, Wu YY, Zhao JJ, Jiang SS, Chao J, Zhang XF, Zhang HX, Zhou ZQ, et al: Decreased TPD52 expression is associated with poor prognosis in primary hepatocellular carcinoma. Oncotarget 7: 6323-6334, 2016.

84. Shimizu D, Kanda M, Nomoto S, Oya H, Takami H, Hibino S, Suenaga M, Inokawa $\mathrm{Y}$, Hishida $\mathrm{M}$, Takano $\mathrm{N}$, et al: Identification of intragenic methylation in the TUSC1 gene as a novel prognostic marker of hepatocellular carcinoma. Oncol Rep 31: 1305-1313, 2014.

85. Wu D, Liu G, Liu Y, Saiyin H, Wang C, Wei Z, Zen W, Liu D, Chen Q, Zhao Z, et al: Zinc finger protein 191 inhibits hepatocellular carcinoma metastasis through discs large 1-mediated yes-associated protein inactivation. Hepatology 64: 1148-1162, 2016.

86. Tsukada Y, Fang J, Erdjument-Bromage H, Warren ME, Borchers $\mathrm{CH}$, Tempst $\mathrm{P}$ and Zhang Y: Histone demethylation by a family of JmjC domain-containing proteins. Nature 439: 811-816, 2006.

87. Zhang R, Huang Q, Li Y, Song Y and Li Y: JMJD5 is a potential oncogene for colon carcinogenesis. Int J Clin Exp Pathol 8: 64826489,2015

88. Zhao Z, Sun C, Li F, Han J, Li X and Song Z: Overexpression of histone demethylase JMJD5 promotes metastasis and indicates a poor prognosis in breast cancer. Int J Clin Exp Pathol 8 : 10325-10334, 2015.

89. Huang X, Zhang S, Qi H, Wang Z, Chen HW, Shao J and Shen J: JMJD5 interacts with p53 and negatively regulates p53 function in control of cell cycle and proliferation. Biochim Biophys Acta 1853: 2286-2295, 2015.
90. Soussi-Yanicostas N, de Castro F, Julliard AK, Perfettini I, Chédotal A and Petit C: Anosmin-1, defective in the X-linked form of Kallmann syndrome, promotes axonal branch formation from olfactory bulb output neurons. Cell 109: 217-228, 2002

91. González-Martínez D, Kim SH, Hu Y, Guimond S, Schofield J, Winyard P, Vannelli GB, Turnbull J and Bouloux PM: Anosmin-1 modulates fibroblast growth factor receptor 1 signaling in human gonadotropin-releasing hormone olfactory neuroblasts through a heparan sulfate-dependent mechanism. J Neurosci 24: 10384-10392, 2004.

92. Jian B, Nagineni CN, Meleth S, Grizzle W, Bland K, Chaudry I and Raju R: Anosmin-1 involved in neuronal cell migration is hypoxia inducible and cancer regulated. Cell Cycle 8: 3770-3776, 2009.

93. Choy CT, Kim H, Lee JY, Williams DM, Palethorpe D, Fellows G, Wright AJ, Laing K, Bridges LR, Howe FA, et al: Anosmin-1 contributes to brain tumor malignancy through integrin signal pathways. Endocr Relat Cancer 21: 85-99, 2013.

94. Kang YK, Hong SW, Lee H and Kim WH: Prognostic implications of ezrin expression in human hepatocellular carcinoma. Mol Carcinog 49: 798-804, 2010.

95. Wang F, Feng Y, Li P, Wang K, Feng L, Liu YF, Huang H, Guo YB, Mao QS and Xue WJ: RASSF10 is an epigenetically inactivated tumor suppressor and independent prognostic factor in hepatocellular carcinoma. Oncotarget 7: 4279-4297, 2016.

96. Matsuzaki T, Hanai S, Kishi H, Liu Z, Bao Y, Kikuchi A, Tsuchida K and Sugino H: Regulation of endocytosis of activin type II receptors by a novel PDZ protein through Ral/Ral-binding protein 1-dependent pathway. J Biol Chem 277: 19008-19018, 2002.

97. Adam MG, Berger C, Feldner A, Yang WJ, WüstehubeLausch J, Herberich SE, Pinder M, Gesierich S, Hammes HP, Augustin $\mathrm{HG}$, et al: Synaptojanin-2 binding protein stabilizes the Notch ligands DLL1 and DLL4 and inhibits sprouting angiogenesis. Circ Res 113: 1206-1218, 2013.

98. Wang J, Sullenger BA and Rich JN: Notch signaling in cancer stem cells. Adv Exp Med Biol 727: 174-185, 2012.

99. Brito GC, Fachel AA, Vettore AL, Vignal GM, Gimba ER, Campos FS, Barcinski MA, Verjovski-Almeida S and Reis EM: Identification of protein-coding and intronic noncoding RNAs down-regulated in clear cell renal carcinoma. Mol Carcinog 47: 757-767, 2008

100. Okamura Y, Nomoto S, Kanda M, Hayashi M, Nishikawa Y, Fujii T, Sugimoto H, Takeda S and Nakao A: Reduced expression of reelin $(R E L N)$ gene is associated with high recurrence rate of hepatocellular carcinoma. Ann Surg Oncol 18: 572-579, 2011.

101. Kanda M, Nomoto S, Okamura Y, Nishikawa Y, Sugimoto H, Kanazumi N, Takeda S and Nakao A: Detection of metallothionein $1 \mathrm{G}$ as a methylated tumor suppressor gene in human hepatocellular carcinoma using a novel method of double combination array analysis. Int J Oncol 35: 477-483, 2009.

102. Nomoto S, Kanda M, Okamura Y, Nishikawa Y, Qiyong L, Fujii T, Sugimoto H, Takeda S and Nakao A: Epidermal growth factor-containing fibulin-like extracellular matrix protein 1 , EFEMP1, a novel tumor-suppressor gene detected in hepatocellular carcinoma using double combination array analysis. Ann Surg Oncol 17: 923-932, 2010.

103. Okamura Y,Nomoto S,Kanda M,LiQ,Nishikawa Y,SugimotoH, Kanazumi N, Takeda S and Nakao A: Leukemia inhibitory factor receptor (LIFR) is detected as a novel suppressor gene of hepatocellular carcinoma using double-combination array. Cancer Lett 289: 170-177, 2010.

104. Kanda M, Nomoto S, Okamura Y, Hayashi M, Hishida M, Fujii T, Nishikawa Y, Sugimoto H, Takeda $S$ and Nakao A: Promoter hypermethylation of fibulin 1 gene is associated with tumor progression in hepatocellular carcinoma. Mol Carcinog 50: 571-579, 2011.

105. Hayashi M, Nomoto S, Kanda M, Okamura Y, Nishikawa Y, Yamada S, Fujii T, Sugimoto H, Takeda S and Kodera Y: Identification of the A kinase anchor protein 12 (AKAP12) gene as a candidate tumor suppressor of hepatocellular carcinoma. $\mathbf{J}$ Surg Oncol 105: 381-386, 2012.

106. Okamura Y, Nomoto S, Hayashi M, Hishida M, Nishikawa Y, Yamada S, Fujii T, Sugimoto H, Takeda S, Kodera Y, et al: Identification of the bleomycin hydrolase gene as a methylated tumor suppressor gene in hepatocellular carcinoma using a novel triple-combination array method. Cancer Lett 312: 150-157, 2011. 
107. Hishida M, Nomoto S, Inokawa Y, Hayashi M, Kanda M, Okamura Y, Nishikawa Y, Tanaka C, Kobayashi D, Yamada S, et al: Estrogen receptor 1 gene as a tumor suppressor gene in hepatocellular carcinoma detected by triple-combination array analysis. Int J Oncol 43: 88-94, 2013.

108. Inokawa Y, Nomoto S, Hishida M, Hayashi M, Kanda M, Nishikawa Y, Takeda S, Fujiwara M, Koike M, Sugimoto H, et al: Dynamin 3: A new candidate tumor suppressor gene in hepatocellular carcinoma detected by triple combination array analysis. Onco Targets Ther 6: 1417-1424, 2013.

109. Inokawa Y, Nomoto S, Hishida M, Hayashi M, Kanda M, Nishikawa Y, Takeda S, Sugimoto H, Fujii T, Yamada S, et al: Detection of doublecortin domain-containing 2 (DCDC2), a new candidate tumor suppressor gene of hepatocellular carcinoma by triple combination array analysis. J Exp Clin Cancer Res 32 65,2013

110. Hayashi M, Nomoto S, Hishida M, Inokawa Y, Kanda M, Okamura Y, Nishikawa Y, Tanaka C, Kobayashi D, Yamada S, et al: Identification of the collagen type $1 \propto 1$ gene $(C O L 1 A 1)$ as a candidate survival-related factor associated with hepatocellular carcinoma. BMC Cancer 14: 108, 2014.

111. Hishida M, Inokawa Y, Takano N, Nishikawa Y, Iwata N, Kanda M, Tanaka C, Kobayashi D, Yamada S, Nakayama G, et al: Protein tyrosine kinase 7: A hepatocellular carcinoma-related gene detected by triple-combination array. J Surg Res 195: 444-453, 2015.

112. Takano N, Hishida M, Inokawa Y, Hayashi M, Kanda M, Nishikawa Y, Iwata N, Kobayashi D, Tanaka C, Yamada S, et al: $C C N J$ detected by triple combination array analysis as a tumor-related gene of hepatocellular carcinoma. Int J Oncol 46: 1963-1970, 2015.

113. Higuchi T, Todaka H, Sugiyama Y, Ono M, Tamaki N, Hatano E, Takezaki Y, Hanazaki K, Miwa T, Lai S, et al: Suppression of microRNA-7 (miR-7) biogenesis by nuclear factor 90-nuclear factor 45 complex (NF90-NF45) controls cell proliferation in hepatocellular carcinoma. J Biol Chem 291: 21074-21084, 2016.

114. You Y, Tan JX, Dai HS, Chen HW, Xu XJ, Yang AG, Zhang YJ, Bai LH and Bie P: MiRNA-22 inhibits oncogene galectin-1 in hepatocellular carcinoma. Oncotarget 7: 57099-57116, 2016

115. Wang Y, Sun B, Zhao X, Zhao N, Sun R, Zhu D, Zhang Y, Li Y, Gu Q, Dong X, et al: Twist1-related miR-26b-5p suppresses epithelial-mesenchymal transition, migration and invasion by targeting SMAD1 in hepatocellular carcinoma. Oncotarget 7: 24383-24401, 2016.

116. Liu Z, Wang J, Mao Y, Zou B and Fan X: MicroRNA-101 suppresses migration and invasion via targeting vascular endothelial growth factor- $C$ in hepatocellular carcinoma cells. Onco Lett 11: 433-438, 2016.

117. Yen CS, Su ZR, Lee YP, Liu IT and Yen CJ: miR-106b promotes cancer progression in hepatitis B virus-associated hepatocellular carcinoma. World J Gastroenterol 22: 5183-5192, 2016.

118. Huan L, Bao C, Chen D, Li Y, Lian J, Ding J, Huang S, Liang L and He X: MicroRNA-127-5p targets the biliverdin reductase $\mathrm{B} /$ nuclear factor- $\kappa \mathrm{B}$ pathway to suppress cell growth in hepatocellular carcinoma cells. Cancer Sci 107: 258-266, 2016

119. Tian Z, Jiang H, Liu Y, Huang Y, Xiong X, Wu H and Dai X: MicroRNA-133b inhibits hepatocellular carcinoma cell progression by targeting Sirt1. Exp Cell Res 343: 135-147, 2016.

120.Zeng YB, Liang XH, Zhang GX, Jiang N, Zhang T, Huang JY, Zhang L and Zeng XC: miRNA-135a promotes hepatocellular carcinoma cell migration and invasion by targeting forkhead box O1. Cancer Cell Int 16: 63, 2016.

121. Sakabe T, Azumi J, Umekita Y, Toriguchi K, Hatano E, Hirooka Y and Shiota G: Prognostic relevance of miR-137 in patients with hepatocellular carcinoma. Liver Int 37: 271-279, 2017.

122. Yu M, Lin Y, Zhou Y, Jin H, Hou B, Wu Z, Li Z, Jian Z and Sun J: MiR-144 suppresses cell proliferation, migration, and invasion in hepatocellular carcinoma by targeting SMAD4. Onco Targets Ther 9: 4705-4714, 2016.

123. Tang B, Lei B, Qi G, Liang X, Tang F, Yuan S, Wang Z, Yu S and He S: MicroRNA-155-3p promotes hepatocellular carcinoma formation by suppressing FBXW7 expression. J Exp Clin Cancer Res 35: 93, 2016.

124. Ruan T, He X, Yu J and Hang Z: MicroRNA-186 targets Yes-associated protein 1 to inhibit Hippo signaling and tumorigenesis in hepatocellular carcinoma. Oncol Lett 11: 2941-2945, 2016
125. Lian J, Jing Y, Dong Q, Huan L, Chen D, Bao C, Wang Q, Zhao F, Li J, Yao M, et al: miR-192, a prognostic indicator, targets the SLC39A6/SNAIL pathway to reduce tumor metastasis in human hepatocellular carcinoma. Oncotarget 7: 2672-2683, 2016.

126. Deng B, Qu L, Li J, Fang J, Yang S, Cao Z, Mei Z and Sun X: MiRNA-211 suppresses cell proliferation, migration and invasion by targeting SPARC in human hepatocellular carcinoma. Sci Rep 6: 26679, 2016.

127. Yu G, Wang J, Xu K and Dong J: Dynamic regulation of uncoupling protein 2 expression by microRNA-214 in hepatocellular carcinoma. Biosci Rep 36: 36, 2016.

128. Okajima W, Komatsu S, Ichikawa D, Miyamae M, Kawaguchi T, Hirajima S, Ohashi T, Imamura T, Kiuchi J, Arita T, et al: Circulating microRNA profiles in plasma: Identification of miR-224 as a novel diagnostic biomarker in hepatocellular carcinoma independent of hepatic function. Oncotarget 7 : 53820-53836, 2016.

129. Meng X, Lu P and Fan Q: miR-367 promotes proliferation and invasion of hepatocellular carcinoma cells by negatively regulating PTEN. Biochem Biophys Res Commun 470: 187-191, 2016.

130. Chen JS, Li HS, Huang JQ, Dong SH, Huang ZJ, Yi W, Zhan GF, Feng JT, Sun JC and Huang XH: MicroRNA-379-5p inhibits tumor invasion and metastasis by targeting FAK/AKT signaling in hepatocellular carcinoma. Cancer Lett 375: 73-83, 2016.

131. Liu S, Liu K, Zhang W, Wang Y, Jin Z, Jia B and Liu Y: miR-449a inhibits proliferation and invasion by regulating ADAM10 in hepatocellular carcinoma. Am J Transl Res 8: 2609-2619, 2016.

132. Zhang L, Yu Z, Xian Y and Lin X: microRNA-497 inhibits cell proliferation and induces apoptosis by targeting YAP1 in human hepatocellular carcinoma. FEBS Open Bio 6: 155-164, 2016.

133. Jin H, Yu M, Lin Y, Hou B, Wu Z, Li Z and Sun J: MiR-502-3P suppresses cell proliferation, migration, and invasion in hepatocellular carcinoma by targeting SET. Onco Targets The 9: 3281-3289, 2016

134. Xiao Y, Tian Q, He J, Huang M, Yang C and Gong L: MiR-503 inhibits hepatocellular carcinoma cell growth via inhibition of insulin-like growth factor 1 receptor. Onco Targets Ther 9: 3535-3544, 2016.

135.Tu K, Liu Z, Yao B, Han S and Yang W: MicroRNA-519a promotes tumor growth by targeting PTEN/PI3K/AKT signaling in hepatocellular carcinoma. Int J Oncol 48: 965-974, 2016.

136. Wang W, Zhang H, Wang L, Zhang S and Tang M: miR-613 inhibits the growth and invasiveness of human hepatocellular carcinoma via targeting DCLK1. Biochem Biophys Res Commun 473: 987-992, 2016.

137. Wu G, Zheng K, Xia S, Wang Y, Meng X, Qin X and Cheng Y: MicroRNA-655-3p functions as a tumor suppressor by regulating ADAM10 and $\beta$-catenin pathway in hepatocellular carcinoma. J Exp Clin Cancer Res 35: 89, 2016.

138. Zhou X, Zhang L, Zheng B, Yan Y, Zhang Y, Xie H, Zhou L, Zheng S and Wang W: MicroRNA-761 is upregulated in hepatocellular carcinoma and regulates tumorigenesis by targeting Mitofusin-2. Cancer Sci 107: 424-432, 2016.

139. Tan G, Wu L, Tan J, Zhang B, Tai WC, Xiong S, Chen W, Yang J and $\mathrm{Li} \mathrm{H}$ : MiR-1180 promotes apoptotic resistance to human hepatocellular carcinoma via activation of NF- $\kappa \mathrm{B}$ signaling pathway. Sci Rep 6: 22328, 2016.

140. Yang J, Zhou F, Xu T, Deng H, Ge YY, Zhang C, Li J and Zhuang SM: Analysis of sequence variations in 59 microRNAs in hepatocellular carcinomas. Mutat Res 638: 205-209, 2008.

141. Ge Y, Yan X, Jin Y, Yang X, Yu X, Zhou L, Han S, Yuan Q and Yang M: MiRNA-192 [corrected] and miRNA-204 directly suppress lncRNA HOTTIP and interrupt GLS1-mediated glutaminolysis in hepatocellular carcinoma. PLoS Genet 11: e1005726, 2015.

142. Cai C, Ashktorab H, Pang X, Zhao Y, Sha W, Liu Y and Gu X: MicroRNA-211 expression promotes colorectal cancer cell growth in vitro and in vivo by targeting tumor suppressor CHD5. PLoS One 7: e29750, 2012.

143. Chen YF, Yang CC, Kao SY, Liu CJ, Lin SC and Chang KW: MicroRNA-211 enhances the oncogenicity of carcinogeninduced oral carcinoma by repressing TCF12 and increasing antioxidant activity. Cancer Res 76: 4872-4886, 2016.

144. Lee H, Lee S, Bae H, Kang HS and Kim SJ: Genome-wide identification of target genes for miR-204 and miR-211 identifies their proliferation stimulatory role in breast cancer cells. Sci Rep 6: 25287, 2016.

145. Ye L, Wang H and Liu B: miR-211 promotes non-small cell lung cancer proliferation by targeting SRCIN1. Tumour Biol 37: $1151-1157,2016$. 
146. Asuthkar S, Velpula KK, Chetty C, Gorantla B and Rao JS Epigenetic regulation of miRNA-211 by MMP-9 governs glioma cell apoptosis, chemosensitivity and radiosensitivity. Oncotarget 3: 1439-1454, 2012.

147.Levy C, Khaled M, Iliopoulos D, Janas MM, Schubert S, Pinner S, Chen PH, Li S, Fletcher AL, Yokoyama S, et al: Intronic miR-211 assumes the tumor suppressive function of its host gene in melanoma. Mol Cell 40: 841-849, 2010.

148.Xia B, Yang S, Liu T and Lou G: miR-211 suppresses epithelial ovarian cancer proliferation and cell-cycle progression by targeting Cyclin D1 and CDK6. Mol Cancer 14: 57, 2015.

149. Ward A, Shukla K, Balwierz A, Soons Z, König R, Sahin O and Wiemann S: MicroRNA-519a is a novel oncomir conferring tamoxifen resistance by targeting a network of tumoursuppressor genes in $\mathrm{ER}^{+}$breast cancer. J Pathol 233: 368-379, 2014.

150.Kim TH, Kim YK, Kwon Y, Heo JH, Kang H, Kim G and An HJ: Deregulation of miR-519a, 153, and 485-5p and its clinicopathological relevance in ovarian epithelial tumours. Histopathology 57: 734-743, 2010.

151.Hong L, Ya-Wei L, Hai W, Qiang Z, Jun-Jie L, Huang A, Song-Tao Q and Yun-Tao L: MiR-519a functions as a tumor suppressor in glioma by targeting the oncogenic STAT3 pathway. J Neurooncol 128: 35-45, 2016.

152. Shao J, Cao J, Liu Y, Mei H, Zhang Y and Xu W: MicroRNA-519a promotes proliferation and inhibits apoptosis of hepatocellular carcinoma cells by targeting FOXF2. FEBS Open Bio 5: 893-899, 2015.

153. Ge YZ, Xu LW, Xu Z, Wu R, Xin H, Zhu M, Lu TZ, Geng LG, Liu H, Zhou CC, et al: Expression profiles and clinical significance of microRNAs in papillary renal cell carcinoma: A STROBE-compliant observational study. Medicine 94: e767, 2015.

154.Zhou X, Zhu HQ, Ma CQ, Li HG, Liu FF, Chang H and Lu J: MiR-1180 promoted the proliferation of hepatocellular carcinoma cells by repressing TNIP2 expression. Biomed Pharmacother 79: 315-320, 2016.

155. Chen PJ, Chen DS, Lai MY, Chang MH, Huang GT, Yang PM, Sheu JC, Lee SC, Hsu HC and Sung JL: Clonal origin of recurrent hepatocellular carcinomas. Gastroenterology 96: 527-529, 1989.

156. Cucchetti A, Piscaglia F, Caturelli E, Benvegnù L, Vivarelli M, Ercolani G, Cescon M, Ravaioli M, Grazi GL, Bolondi L, et al: Comparison of recurrence of hepatocellular carcinoma after resection in patients with cirrhosis to its occurrence in a surveilled cirrhotic population. Ann Surg Oncol 16: 413-422, 2009.

157. Okamoto M, Utsunomiya T, Wakiyama S, Hashimoto M, Fukuzawa K, Ezaki T, Hanai T, Inoue H and Mori M: Specific gene-expression profiles of non-cancerous liver tissue predict the risk for multicentric occurrence of hepatocellular carcinoma in hepatitis C virus-positive patients. Ann Surg Oncol 13: 947-954, 2006.
158. Hoshida Y, Villanueva A, Kobayashi M, Peix J, Chiang DY Camargo A, Gupta S, Moore J, Wrobel MJ, Lerner J, et al: Gene expression in fixed tissues and outcome in hepatocellular carcinoma. N Engl J Med 359: 1995-2004, 2008.

159. Utsunomiya T, Shimada M, Imura S, Morine Y, Ikemoto T and Mori M: Molecular signatures of non-cancerous liver tissue can predict the risk for late recurrence of hepatocellular carcinoma. J Gastroenterol 45: 146-152, 2010

160. Utsunomiya T, Ishikawa D, Asanoma M, Yamada S, Iwahashi S, Kanamoto M, Arakawa Y, Ikemoto T, Morine Y, Imura S, et al: Specific miRNA expression profiles of non-tumor liver tissue predict a risk for recurrence of hepatocellular carcinoma. Hepatol Res 44: 631-638, 2014.

161. Utsunomiya T, Shimada M, Morine Y, Tajima A and Imoto I: Specific molecular signatures of non-tumor liver tissue may predict a risk of hepatocarcinogenesis. Cancer Sci 105: 749-754, 2014.

162. Meckelein B, de Silva HA, Roses AD, Rao PN, Pettenati MJ, Xu PT, Hodge R, Glucksman MJ and Abraham CR: Human endopeptidase (THOP1) is localized on chromosome 19 within the linkage region for the late-onset Alzheimer disease AD2 locus. Genomics 31: 246-249, 1996.

163. Qi L, Li SH, Si LB, Lu M and Tian H: Expression of THOP1 and its relationship to prognosis in non-small cell lung cancer. PLoS One 9: e106665, 2014.

164. Nomoto S, Hishida M, Inokawa Y, Takano N, Kanda M, Nishikawa Y, Fujii T, Koike M, Sugimoto H and Kodera Y: Expression analysis of THOP1 in background liver, a prognostic predictive factor in hepatocellular carcinoma, extracted by multiarray analysis. Ann Surg Oncol 21 (Suppl 3): S443-S450, 2014.

165. Cressman DE, Diamond RH and Taub R: Rapid activation of the Stat 3 transcription complex in liver regeneration. Hepatology 21: 1443-1449, 1995.

166. Calvisi DF, Ladu S, Gorden A, Farina M, Conner EA, Lee JS, Factor VM and Thorgeirsson SS: Ubiquitous activation of Ras and Jak/Stat pathways in human HCC. Gastroenterology 130: 1117-1128, 2006.

167. Sonohara F, Nomoto S, Inokawa Y, Hishida M, Takano N, Kanda M, Nishikawa Y, Fujii T, Koike M, Sugimoto H, et al: High expression of Janus kinase 2 in background normal liver tissue of resected hepatocellular carcinoma is associated with worse prognosis. Oncol Rep 33: 767-773, 2015. 